\title{
URGENSI PENDIDIKAN KEWIRAUSAHAAN DALAM MENGHASILKAN WIRAUSAHAWAN MUDA DARI PERGURUAN TINGGI
}

\author{
Hasni \\ Institut Agama Islam Negeri Bone, Indonesia \\ e-mail:hasni.abdsalam@gmail.com
}

\begin{abstract}
This article reviews the urgency of entrepreneurship education in universities. The study was carried out through a process of analyzing various sources from literature and journals related to entrepreneurship. Discussion result shows that entrepreneurship education is very important to be applied in universities in any department to produce graduates with entrepreneurial mentality who is able to open employment opportunities to support the progress of the country's economy.
\end{abstract}

Key words: entrepreneurship education, university

\section{Pendahuluan}

Dalam rangka turut berpartisipasi dalam pembangunan negara, sebagai warganegara harusnya ikut andil, apapun profesinya. Hal ini bisa dilakukan dengan turut mendukung program pemerintah. Salah satu program pemerintah yakni meningkatkan jumlah wirausahawan untuk mendukung visi Indonesia menjadi Negara maju di tahun 2045. ${ }^{1}$ Salah satu indicator negara maju adalah terciptanya lapangan pekerjaan yang lebih banyak. Hal ini tidak mungkin terjadi jika para lulusan dari perguruan tinggi bergantung pada lapangan pekerjaan yang dibuka oleh pemerintah. Untuk mewujudkan visi tersebut, Indonesia harus menambah jumlah pengusaha (wirausahawan) yang tidak hanya bergantung pada aspek sumberdaya alam tapi juga mampu bergerak di bidang industri.

Jika dibandingkan dengan negara-negara lain di dunia, maka jumlah wirausahawan di Indonesia masih tergolong sedikit.

Gambar 1. Data Rasio Pengusaha Terhadap Jumlah Penduduk Di Beberapa Negara 2013

1“Tiga Tahapan Pembangunan Menuju Indonesia 2045” (BerandaAktual), presidenri.go.id,27 Maret 2017, diakses tanggal 6 November 2018, h.1 

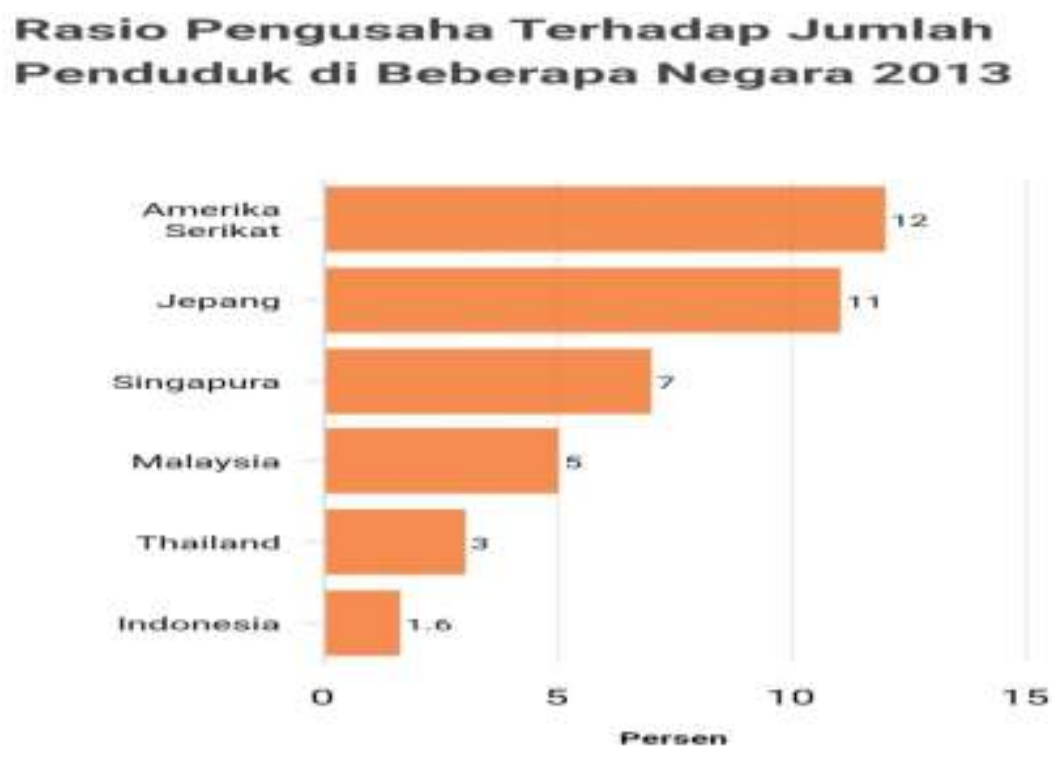

Sumber: katadata.co.id $(2018)^{2}$

Berdasarkan data di atas, terlihat bahwa jumlah pengusaha di Indonesia masih sedikit karena masih di bawah 2\%. Selanjutnya sampai tahun 2017, rasio pengusaha di Indonesia sudah naik menjadi 3,1\%. Hal ini sesuai dengan pernyataan dari Bapak Puspayoga selaku Menteri Koperasi dan UKM dalam acara Gerakan Kewirausahaan Nasional (GKN) 2017 di Institut Pertanian Bogor (IPB) pada Maret 2017. Beliau mengatakan: "rasio wirausaha Indonesia yang pada 2013/2014 lalu masih 1,67\% kini berdasarkan data BPS naik menjadi 3,1\%"3. Meskipun sudah mengalami peningkatan, jumlah wirausahawan di Indonesia masih jauh di bawah negara-negara lainnya. Hal ini terlihat dari pernyataan presiden Republik Indonesia, Bapak Joko Widodo: "hampir di setiap Negara maju, standarnya itu memiliki (penduduk) entrepreneur di atas 14\%. Sementara kita, angkanya masih 3,1\%. Artinya perlu percepatan"4.

Seiring dengan keinginan pemerintah untuk mewujudkan visi Indonesia di tahun 2045, kementerian koperasi dan UKM terus berusaha meningkatkan jumlah wirausahawan di Indonesia. Usaha tersebut sudah mulai membuahkan hasil karena di tahun 2018 ini, rasio wirausaha di Indonesia meningkat menjadi tujuh persen lebih dari total penduduk Indonesia. ${ }^{5}$

\footnotetext{
${ }^{2}$ Katadata.co.id, diakses tanggal 29 Oktober 2018.

${ }^{3}$ Humas Kementerian Koperasidan UKM, "Ratio Wirausaha Indonesia Naik Jadi 3,1" (Siaran Pers), www.depkop.go.id, 11 Maret 2017, h.1

${ }^{4}$ Fabian Januarius Kuwado, "Jumlah Entrepreneur Di Indonesia Jauh Di Bawah Negara Maju, Ini Kata Jokowi” (News Nasional). www.Kompas.com, 5 April 2018, h.1

5"Menteri Puspayoga Sebut Rasio Wirausaha sudah Capai 7 Persen Lebih" (Berita Media), www.depkop.go.id, 6 Juni 2018, h.1
} 
Untuk mencetak wirausahawan, bisa dilakukan dari tingkat perguruan tinggi. Hal ini didukung penuh oleh Kementerian Riset, Teknologi, dan PendidikanTinggi melalui Direktorat Jenderal Pembelajaran dan Kemahasiswaan. Salah satu fungsi dari Direktorat Kemahasiswaan adalah fasilitasi di bidang penalaran, kreativitas, kesejahteraan mahasiswa, kewirausahaan, minat dan bakat, organisasi kemahasiswaan, serta penyelarasan dunia kerja. ${ }^{6}$

Pendidikan kewirausahaan di perguruan tinggi telah difasilitasi oleh Dikti sejak tahun 1997 dengan adanya program pengembangan kewirausahaan yang menawarkan berbagai kegiatan yaitu Kuliah Kewirausahaan (KWU), Magang Kewirausahaan (MKU), Kuliah Kerja Usaha (KKU), Konsultasi Bisnis Dan Penempatan Kerja (KBPK), dan Inkubator Perusahaan Baru (INWUB). ${ }^{7}$

Perguruan tinggi sebagai bagian yang penting bagi peningkatan pendidikan dari bangsa ini, perlu berupaya lebih untuk mendukung pemerintah dalam menghasilkan lulusan dari berbagai bidang ilmu sebagai pembuka lapangan pekerjaan, bukan sekedar pencari lapangan pekerjaan demi tercapainya Indonesia sebagai negara maju di tahun 2045 nanti.

\section{Kewirausahaan}

Jika berbicara tentang wirausaha maka hal tersebut sering diidentikkan dengan wiraswasta, pengusaha, ataupun pedagang. Untuk mengetahui arti sebenarnya dari wirausaha, perlu dilihat pengertiannya.

Secara etimologis, kata entrepreneur berasal dari bahasa Prancis entreprendere yang artinya usaha berani, petualang, pencipta, dan pengelola usaha. Dalam Bahasa Indonesia, semakna dengan kata wirausaha. Wira berasal dari bahasa Sansekerta yang berarti berani. Istilah entrepredere diperkenalkan pertama kali oleh Richard Cantillon (1755). Secara epistimologi, entrepreneurship adalah suatu nilai yang diperlukan untuk memulai suatu usaha (start-up)atau suatu proses dalam mengerjakan sesuatu yang baru (creative)dan sesuatu yang berbeda (innovative). Dalam International Conference of Entrepreneurship di Amerika tahun 2010, disepakati bahwa entrepreneur is a word view about creation. Jadi inti yang membedakan seorang entrepreneur adalah adanya unsur kekaryaan. ${ }^{8}$

Secara konseptual, seorang wirausahawan dapat didefiniskan dari beberapa sudut pandang dan konteks sebagai berikut: ${ }^{9}$

\footnotetext{
${ }^{6}$ Direktorat Jenderal Pembelajaran dan Kemahasiswaan. Fungsi Direktorat Kemahasiswaan, belmawa.ristekdikti.go.id, 9 Desember 2016

${ }^{7}$ Susilaningsih, "Pendidikan Kewirausahaan Di Perguruan Tinggi: Pentingkah Untuk Semua Profesi?", Jurnal Economia. Vol. 11, No. 1, April 2015, h. 1-2.

${ }^{8}$ Agus Santoso, 9 Kunci Sukses Entrepreneur (Cet. I; Jakarta: Bestari, 2016), h. 281-282.

${ }^{9}$ Suryana, Kewirausahaan: Kiat dan Proses Menuju Sukses (Edisi 4; Jakarta: Salemba Empat, 2017), h. 12.
} 
1. Pandangan ahli ekonomi, wirausahawan adalah orang yang mengombinasikan faktor-faktor produksi, seperti sumber daya alam, tenaga kerja/ sumber daya manusia, material, dan peralatan lainnya untuk meningkatkan nilai yang lebih tinggi dari sebelumnya

2. Pandangan ahli manajemen, wirausahawan adalah seseorang yang memiliki kemampuan dalam menggunakan dan mengombinasikan sumber daya seperti keuangan, bahan mentah, tenaga kerja, keterampilan, dan informasi untuk menghasilkan produk baru, proses produksi baru, bisnis baru, dan organisasi usaha baru ${ }^{10}$

3. Pandangan pelaku bisnis, wirausahawan adalah orang yang bertindak kreatif membentuk nilai terhadap sesuatu secara praktis.

4. Pandangan psikolog wirausahawan adalah orang yang memiliki dorongan kekuatan dari dalam dirinya untuk memperoleh suatu tujuan, suka menguji coba atau bereksperimen untuk menampilkan kebebasan dirinya di luar kekuasaan orang lain.

5. Pandangan pemodal, wirausahawan adalah orang yang menciptakan kesejahteraan untuk orang lain, menemukan cara-cara baru untuk menggunakan sumber daya, mengurangi pemborosan, dan membuka lapangan kerja yang disenangi masyarakat

Arti kata Sansekerta dari wiraswasta menurut Salim Siagian dan Ashafani (1995) adalah wira berarti utama, gagah, luhur, berani, teladan, atau pejuang; swa berarti sendiri; sta berarti berdiri; swasta berarti berdiri di atas kaki sendiri atau dengan kata lain berdiri di atas kemampuan sendiri. ${ }^{11}$

Wirausaha(entrepreneur) selalu dilekatkan dengan inovasi dan kreatifitas. Seorang yang berwiraswasta belum tentu memiliki inovasi dan kreatifitas. Seorang pedagang yang hanya sekedar membeli barang dan menjualnya kembali tidak dapat disebut wirausahawan. Tetapi seseorang yang tidak berdagang (mencari uang dengan melakukan pekerjaan lain selain berdagang) bisa disebut sebagai wirausahawan jika kegiatannya didukung dengan inovasi dan kreatifitas karena yang membedakan wirausaha dengan wiraswasta, pedagang, ataupun pengusaha pada dasarnya adalah mindset (cara berpikir) nya. Bisa dilihat pada pembahasan berikutnya tentang karakteristik wirausaha.

\section{Pendidikan Kewirausahaan}

Pendidikan kewirausahaan di Indonesia sebaiknya dilakukan secara bersama-sama oleh pemerintah, tenaga pendidik, dan orang tua. Ketiganya harus

\footnotetext{
${ }^{10}$ Marzuki Usman, "Kewirausahaan dalam Birokrasi Salah Satu Langkah Antisipatif Menghadapi Globalisasi”, dalam Suryana, eds., Kewirausahaan: Kiat dan Proses Menuju Sukses (Edisi 4; Jakarta: Salemba Empat, 2017), h. 12.

${ }^{11}$ Farid, Kewirausahaan Syariah (Jakarta: Kencana, 2017), h. 10.
} 
bersinergi untuk menanamkan mental berwirausaha bagi para mahasiswa. Mental kewirasahaan yang dimaksud adalah mental membuka lapangan pekerjaan, bukan mencari lapangan pekerjaan. Pekerjaan ini memang tidak mudah karena mental mencari lapangan pekerjaanlah yang banyak dimiliki setelah mahasiswa menyelesaikan kuliah di perguran tinggi.

Mengubah mental dari pencari kerja menjadi pembuka lapangan pekerjaan bukan pekerjaan mudah. Perubahan tidak dapat dilakukan secara instan, tetapi harus dilakukan secara bertahap, dengan memberikan contoh-contoh yang diberikan pada masyarakat: ${ }^{12}$

1. Mendirikan sekolah berwawasan kewirausahaan atau paling tidak memasukkan mata kuliah kewirausahaan dalam kurikulum sebagaimana yang telah dijalankan di berbagai pergutuan tinggi.

2. Di dalam pendidikan kewirausahaan perlu ditekankan keberanian untuk memulai berwirausaha. Kendalanya ada pada pelajar atau mahasiswa adalah rasa takut akan rugi atau bangkrut

3. Tidak sedikit mereka merasa bahwa berwirausaha sama dengan tidak memiliki masa depan yang pasti. Sementara jika bekerja di perusahaan atau pemerintah, mereka yakin bahwa masa depan ada di tangan kita sendiri bukan di tangan orang lain.

Beberapa pembekalan program Kewirausahaan yang dapat dilakukan di perguruan tinggi dalam mempersiapkan para lulusannya sebagai calon wirausaha baru sebagai berikut: ${ }^{13}$

1. Program Mahasiswa Wirausaha (PMW)

2. Program Kuliah Kewirausahaan (KWU)

3. Program Magang Kewirausahaan (MKU)

4. Program Kuliah Kerja Usaha (KKU)

5. Inkubator Wirausaha Baru (INWUB) perguruan tinggi yang berminat menjadi wirausahawan dengan biaya terjangkau selama jangka waktu tertentu (2-3 tahun)

\section{Metode Penelitian}

Metode kajian ini dilakukan dengan cara sederhana yaitu dengan menganalisis berbagai dokumen sebagai sumber acuan yang terkait dengan pendidikan Kewirausahaan yakni dari pembahasan kewirausahaan dari jurnal dan teori-teori pendukung.

\footnotetext{
${ }^{12}$ Farid, Kewirausahaan Syariah, h. 4-5.

${ }^{13}$ Siswo Wiratno, "Pelaksanaan Pendidikan Kewirausahaan Di Pendidikan Tinggi”. Jurnal Pendidikan dan Kebudayaan. Vol. 18, No. 4, Desember 2012, h. 456 - 458
} 


\section{Pembahasan}

Pendidikan kewirausahaan tentu saja perlu diterapkan di perguruan tinggi karena dianggap mampu memberikan pengaruh yang positif bagi setiap lulusan perguruan tinggi. Jadi sudah sewajarnya Kementerian Riset, Teknologi, dan PendidikanTinggi mendukung adanya pendidikan kewirausahaan di perguruan tinggi dengan berfungsi sebagai fasilitasi bidang kewirausahaan. Banyak penelitian yang menunjukkan bahwa pendidikan kewirausahaan memberikan pengaruh positif pada minta, motivasi, maupun keterampilan berwirausaha yang nantinya berguna bagi lulusan perguruan tinggi sebagai bekal untuk terjun di dunia kerja baik bergabung dalam suatu korporasi maupun menjadi pemilik korporasi.

Salah satu hasil penelitian yang dilakukan terhadap 88 mahasiswa fakultas ekonomi dan bisnis Universitas 17 Agustus 1945 Jakarta $^{14}$ menunjukkan bahwa pendidikan kewirausahaan berpengaruh positif dan signifikan terhadap keterampilan berwirausaha. Motivasi kewirausahaan berpengaruh positif dan signifikan terhadap keterampilan berwirausaha. Diharapkan dengan adanya pendidikan kewirausahaan, mahasiswa memiliki motivasi dan keterampilan berwirausaha setelah lulus kuliah. Penelitian lain ${ }^{15}$ yang dilakukan terhadap 76 mahasiswa Manajamen, Akuntansi, dan Sosiologi pada Universitas Bangka Belitung menunjukkan terdapat pengaruh positif pembelajaran kewirausahaan terhadap minat berwirausaha.

Pada Universitas Bunda Mulia juga dilakukan penelitian terhadap mahasiswa yang mengambil mata kuliah Kewirausahaan. ${ }^{16}$ Pada penelitian ini menunjukkan hasil bahwa secara statistik tidak ada perbedaan yang signifikan niat berwirausaha terhadap mahasiswa baik sebelum maupun setelah mengambil mata kuliah Kewirausahaan. Dalam penelitian ini, penulis menyatakan bahwa hal ini bisa saja terjadi jika pengajar tidak mampu memberikan sistem pengajaran yang menarik. Perlu pula dihadirkan wirausahawan untuk mengajar dan membawa atmosfir wirausaha secara langsung terhadap mahasiswa. Materi pembelajaran kewirausahaan harus dapat memotivasi untuk berwirausaha, metode pembelajaran yang dapat menumbuhkan minat wirausaha, kemampuan guru yang dapat

\footnotetext{
${ }^{14}$ Doddy Astya Budi, "Pengaruh Pendidikan Kewirausahaan dan Motivasi Kewirausahaan Terhadap Keterampilan Berwirausaha Mahasiswa Universitas 17 Agustus 1945 Jakarta”, Journal For Business And Entrepreneur, Vol.1, No.1, Juli - Desember 2017, h.7

${ }^{15}$ Christianingrum dan Erita Rosalina, "Pengaruh Pembelajaran Kewirausahaan Terhadap Minat Berwirausaha", Integrated Jornal of Business and Economics, Vol.1, No. 1, 2017, h. 54.

${ }^{16}$ Budi dan Fabianus Fensi, "Pengaruh Pendidikan Kewirausahaan dalam Menumbuhkan Minat Berwirausaha", Jurnal Pengabdian dan Kewirausahaan, Vol. 2, No. 1, 2018, h. 7.
} 
menumbuhkan minat wirausaha, serta pengalaman langsung yang dapat menumbuhkan minat berwirausaha. ${ }^{17}$

Penelitian lain yang dilakukan terhadap 68 mahasiswa STIEPARI Semarang menunjukkan hasil bahwa pendidikan kewirausahaan dan dukungan akademik secara positif dan signifikan berpengaruh terhadap niat kewirausahaan mahasiswa. ${ }^{18}$ Penelitian serupa dilakukan terhadap 100 mahasiswa Unmas Denpasar. Hasil penelitian menunjukkan bahwa pemberian mata kuliah dan pelatihan wirausaha kreatif sama-sama memberikan pengaruh positif signifikan terhadap minat wirausaha kreatif. ${ }^{19}$

Zubaedi $^{20}$ dalam tulisannya menguraikan jumlah lulusan dari perguruan tinggi di Indonesia yang tidak sebanding dengan jumlah lapangan pekerjaan yang tersedia. Hal ini menyebabkan meningkatnya pengangguran. Jika seluruh lulusan perguruan tinggi hanya menggantungkan dirinya untuk mencari pekerjaan (bukan membuka lapangan pekerjaan) maka jumlah pengangguran dipastikan akan terus meningkat. Untuk mengatasi hal tersebut maka salah satu upaya yang dapat dilakukan oleh lembaga pendidikan termasuk Perguruan Tinggi Agama Islam (PTKI) adalah memberikan pendidikan kewirausahaan.

Menurut Agus Wibowo ${ }^{21}$, terdapat dua cara untuk menanamkan mental kewirausahaan kepada para mahasiswa di kampus. Pertama, mengintegrasikan pendidikan kewirausahaan ke dalam kurikulum Dalam kurikulum, karakter keilmuan kewirausahaan sebaiknya didesain untuk mengetahui (to know), melakukan (to do), dan menjadi (to be) entrepreneur. Kedua, aktivitas ekstrakurikuler mahasiswa perlu dikemas sistemik dan diarahkan untuk membangun motivasi dan sikap mental wirausaha. Pembinaan mahasiswa dalam berbagai kegiatan minat dan bakat, keilmuan, kesejahteraan atau keorganisasian hendaknya juga diarahkan untuk memberikan keterampilan berwirausaha.

Selama konsep-konsep pembelajaran yang diterapkan di perguruan tinggi tidak mencerminkan kebutuhan lapangan dan dunia kerja, ini sangat berisiko

\footnotetext{
${ }^{17}$ Eman Suherman, "Desain Pembelajaran Kewirausahaan", dalam Christianingrum dan Erita Rosalina, Pengaruh Pembelajaran Kewirausahaan Terhadap Minat Berwirausaha (Integrated Jornal of Business and Economics, Vol.1, No. 1, 2017), h. 49.

${ }^{18}$ Aurilia Triani Aryaningtyas dan Dyah Palupiningtyas, "Pengaruh Pendidikan Kewirausahaan dan Dukungan Akademik Terhadap Niat Kewirausahaan Mahasiswa (Studi Pada Mahasiswa STIEPARI Semarang)", Jurnal Ilmiah Manajemen dan Bisnis, Vol. 18, No. 2, Oktober 2017, h. 140.

${ }^{19}$ I Wayan Widnyana, dkk, "Pengaruh Pemberian Mata Kuliah Kewirausahaan Terhadap Minat WirausahaEkonomi Kreatif Pada Mahasiswa Unmas Denpasar", Jurnal Bakti Masyarakat Indonesia, Vol. 1, No. 1, Mei 2018, h. 176.

${ }^{20}$ Zubaedi, "Urgensi Pendidikan Kewirausahaan Di Kalangan Mahasiswa PTKI", Madania, Vol. 19, No. 2, Desember 2015, h. 149.

${ }^{21}$ Agus Wibowo, "Pendidikan Kewirausahaan (Konsep dan Strategi)", dalam Doddy Astya Budi, eds., Pengaruh Pendidikan Kewirausahaan dan Motivasi Kewirausahaan Terhadap Keterampilan Berwirausaha Mahasiswa Universitas 17 Agustus 1945 Jakarta (Journal For Business And Entrepreneur, Vol.1, No.1, Juli - Desember 2017), h.11.
} 
tinggi untuk membuat peserta didik tidak paham terhadap kenyataan yang ada di hadapan mereka. PTKI perlu melakukan inovasi dalam pendidikan wirausahawan agar alumninya bisa memberikan kontribusi lebih maksimal dalam pembangunan ekonomi bangsa. ${ }^{22}$ Yang perlu diketahui dengan jelas bahwa pendidikan kewirausahaan tidak semata mengajarkan mahasiswa untuk pandai berdagang (berbisnis) tetapi lebih kepada penanaman mental wirausaha yang di dalamnya ada semangat pantang menyerah, berani mengambil risiko, pandai melihat peluang, berjiwa kreatif dan penuh inovasi. Seperti yang ditegaskan oleh Agus Santoso $^{23}$ bahwa wirausahawan (entrepreneur) adalah gabungan dari kekuatan mindset dan perilaku, yang memiliki kekuatan positive thinking, yang punya visi pengembangan jauh ke depan, punya orientasi membangun sistem, tidak hanya berorientasi profit sesaat.

Prinsip-prinsip kewirausahaan yang seperti tersebut di atas itulah yang harus diterapkan dalam sistem pembelajaran pada pendidikan kewirausahaan di perguruan tinggi di Indonesia. Jadi pendidikan kewirausahaan di perguruan tinggi harusnya tidak hanya mengajarkan mahasiswa untuk berdagang, apalagi jika hanya dilakukan dengan sistem simulasi di kelas tetapi mahasiswa harusnya diajarkan untuk terjun langsung ke dunia wirausaha, berhubungan langsung dengan orang-orang yang berkecimpung dalam dunia usaha sehingga mental wirausaha akan terbentuk dari pengalaman bersama dengan orang-orang tersebut.

Seiring dengan keinginan pemerintah untuk terus meningkatkan jumlah wirausahawan di Indonesia dalam rangka mendukung kemajuan perekonomian negara, maka berbagai upaya telah dilakukan. Salah satunya adalah keterlibatan lembaga keuangan dan kampus dalam mendorong bertambahnya jumlah wirausahawan muda di Indonesia. Bank Mandiri mengadakan program Wirausaha mandiri yang telah melahirkan 34 ribu wirausaha muda. IPB sudah memiliki direktorat pengembangan karir dan wirausaha sebagai sarana belajar wirausaha mahasiswa yang sampai saat ini bisa menghasilkan 5\% wirausahawan dari lulusannya. $^{24}$

\section{Pendidikan Kewirausahaan di Beberapa Negara}

Sebelum melihat bagaimana urgensi pendidikan kewirausahaan bagi mahasiswa di perguruan tinggi, maka kita bisa melihat bagaimana pendidikan kewirausahaan dilakukan di beberapa negara untuk bisa menghasilkan wirausahawan-wirausahawan muda.

\footnotetext{
${ }^{22}$ Zubaedi, "Urgensi Pendidikan Kewirausahaan Di Kalangan Mahasiswa PTKI", Madania, h. 153.

${ }^{23}$ Agus Santoso, 9 Kunci Sukses Entrepreneur (Cet. I; Jakarta: Bestari, 2016), h. 281.

${ }^{24}$ Humas Kementerian Koperasidan UKM, "Ratio Wirausaha Indonesia Naik Jadi 3,1" (Siaran Pers), www.depkop.go.id, 11 Maret 2017, h.1
} 
Salah satu negara maju yang bisa dijadikan contoh dalam pendidikan kewirausahawan bagi mahasiswanya adalah Singapura. Singapura adalah negara maju yang awalnya adalah kampung nelayan. Singapura mempunyai perhubungan dagang yang kuat, pelabuhan yang sibuk, dan Pendapatan Domestik Bruto per kapita yang setara dengan negara-negara maju di Eropa Barat. ${ }^{25}$ Rasio wirausahawan di Singapura jauh di atas Indonesia. Salah satu Universitas terbaik dan menjadi pilihan mahasiswa asing adalah National University of Singapore (NUS). Untuk mendukung lahirnya wirausahawan dari perguruan tinggi, NUS menyediakan program minor technopreneurship untuk mahasiswa S1 dari bidang apapun. Sedangkan bagi mahasiswa pasca sarjana, Master dan $\mathrm{PhD}$ yang ingin mengkomersialisasikan temuannya, disediakan matakuliah pilihan new venture creation. ${ }^{26}$

Pendidikan kewirausahaan di perguruan tinggi di China lebih ditekankan pada penciptaan business entrepreneur. Setiap tahun secara bergantian universitas-universitas menyelenggarakan kompetisi Business Plan Nasional yang diikuti oleh mahasiswa dari hampir semua perguruan tinggi di China. Beberapa universitas memiliki inkubator untuk memfasilitasi mahasiswa yang memulai usaha. Di setiap kota, tersedia inkubator yang disediakan untuk wirausahawirausaha muda. Inkubator-inkubator ini didirikan oleh organisasiorganisasi pemerintah dan memberikan pelayanan kepada wirausaha dengan harga yang layak. Beberapa perusahaan menengah memfasilitasi kegiatan-kegiatan wirausaha. ${ }^{27}$

Sementara di Finlandia, School of Economics, Turku, pendidikan kewirausahawan dilakukan untuk menyiapkan mahasiswa menjadi corporate entrepreneur yaitu wirausaha yang berada dalam suatu korporasi. Mahasiswa dilatih mulai dari tahap pemicu, tahap pemberian pengetahuan tentang kewirausahaan sampai tahap keterampilan berperilaku extrepreneurially di dalam suatu organisasi. ${ }^{28}$ Hal ini bisa menunjukkan bagaimana kewirausahaan tidak hanya berlaku di lingkungan usaha atau bisnis tetapi juga berpengaruh positif pada siapa pun dalam profesi apa pun.

W. Chan Kim dan Renee Mauborgne ${ }^{29}$ memberikan contoh seorang komisaris polisi New York mampu mengubah keadaan wilayah kerjanya dari

\footnotetext{
${ }^{25}$ Mohammad Kosim, "Belajar Dari Negara Tetangga Singapora", Karsa, Vol. XVIII, No. 2, Oktober 2010, h. 102.

${ }^{26}$ Susilaningsih, "Pendidikan Kewirausahaan Di Perguruan Tinggi: Pentingkah Untuk Semua Profesi?”, Jurnal Economia, Vol.11, No. 1, April 2015, h. 6.

${ }^{27}$ Susilaningsih, "Pendidikan Kewirausahaan Di Perguruan Tinggi: Pentingkah Untuk Semua Profesi?", h. 6.

${ }^{28}$ Susilaningsih, "Pendidikan Kewirausahaan Di Perguruan Tinggi: Pentingkah Untuk Semua Profesi?", h. 7 - 8.

${ }^{29} \mathrm{~W}$. Chan Kim dan Renee Mauborgne, Blue Ocean Strategy, Terj. Adi Toha, Blue Ocean Strategy (Jakarta: Noura Books, 2016), h. 176.
} 
wilayah yang sangat rawan kejahatan menjadi wilayah yang paling aman melalui konsep kewirausahaan (penerapan konsep Blue Ocean) di tempat kerjanya. Blue Ocean diterapkan dengan mengatasi semua hambatan utama organisasi tanpa ada peningkatan penggunaan anggaran. Hal tersebut sejalan dengan pernyataan dari UNESCO $^{30}$ yang menyatakan bahwa pendidikan kewirausahaan bukan pendidikan usaha (enterprise education) sehingga pendidikan kewirausahaan tidak hanya berfokus pada bisnis.

\section{Urgensi Pendidikan Kewirausahaan}

Banyak pernyataan yang mendukung bahwa sebenarnya pendidikan kewirausahaan tidak hanya penting dalam dunia bisnis tetapi bisa berlaku dalam semua profesi. Begitu pula dengan perguruan tinggi yang pada dasarnya akan menghasilkan lulusan dari berbagai bidang atau jurusan. Hal ini juga didukung oleh Peraturan pemerintah di Indonesia ${ }^{31}$ yang menyatakan bahwa pendidikan tinggi bertujuan (1) membentuk insan yang (a) beriman dan bertakwa kepada Tuhan Yang Maha Esa, berakhlak mulia, dan berkepribadian luhur; (b) sehat, berilmu, dan cakap; (c) kritis, kreatif, inovatif, mandiri, percaya diri dan berjiwa wirausaha; serta (d) toleran, peka sosial dan lingkungan, demokratis, dan bertanggung jawab dan (2) menghasilkan produk-produk ilmu pengetahuan, teknologi, seni, atau olahraga yang memberikan kemaslahatan bagi masyarakat, bangsa, negara, umat manusia, dan lingkungan.

Susilaningsih $^{32}$ menegaskan bahwa pendidikan kewirausahaan di perguruan tinggi diperlukan dalam bidang apapun tanpa memperhatikan bidang yang ditekuni atau profesi seseorang. Oleh karena itu pendidikan kewirausahaan dapat dilaksanakan di perguruan tinggi dan diberlakukan kepada semua mahasiswa tanpa memandang bidang ilmu yang dipelajari, karena pendidikan kewirausahaan bukan pendidikan bisnis.

Masalah pengangguran terdidik yang terus bertambah hanya karena lulsan perguruan tinggi hanya menggantungkan masa depannya dengan terus mencari lapangan pekerjaan atau bergantung pada lapangan pekerjaan yang disediakan oleh pemerintah bisa diselesaikan dengan menumbuhkan minat atau motivasi berwirausaha bagi para mahasiswa. Pendidikan kewirausahaan dapat dijadikan sebagai dasar bagi lulusan perguruan tinggi untuk mengubah pola pikir pencari

${ }^{30}$ UNESCO, "Inter-Regional Seminar on Promoting Entrepreneurship Education in Secondary School Tahun 2008", dalam Susilaningsih, "Pendidikan Kewirausahaan Di Perguruan Tinggi: Pentingkah Untuk Semua Profesi?”, Jurnal Economia, Vol.11, No. 1, April 2015, h. 5.

${ }^{31}$ Republik Indonesia, "Peraturan Pemerintah Nomor 17 tahun 2010 Tentang Pengelolaan Dan Penyelenggaraan Pendidikan", dalam Susilaningsih, "Pendidikan Kewirausahaan Di Perguruan Tinggi: Pentingkah Untuk Semua Profesi?", h. 5

${ }^{32}$ Susilaningsih, "Pendidikan Kewirausahaan Di Perguruan Tinggi: Pentingkah Untuk Semua Profesi?", h. 1. 
kerja menjadi pembuka lapangan pekerjaan. Semakin banyak wirausahawan lulusan perguruan tinggi maka semakin besar pula peluang terbukanya lapangan pekerjaan yang pada akhirnya akan mendukung pemerintah menuju tercapainya visi menjadi negara maju di tahun 2045 .

\section{Simpulan}

Pendidikan kewirausahaan penting diterapkan di perguruan tinggi di jurusan apa pun untuk menghasilkan lulusan yang siap terjun ke dunia kerja, baik itu sebagai bagian dari korporasi maupun sebagai pemilik korporasi. Lulusan perguruan tinggi diharapkan memiliki mental wirausaha yang didapatkan dari pendidikan kewirausahaan yaitu sebagai pembuka lapangan pekerjaan, bukan sebagai pencari lapangan pekerjaan.

\section{Daftar Pustaka}

Aryaningtyas, Aurilia Triani dan Dyah Palupiningtyas, "Pengaruh Pendidikan Kewirausahaan dan Dukungan Akademik Terhadap Niat Kewirausahaan Mahasiswa (Studi Pada Mahasiswa STIEPARI Semarang)", Jurnal Ilmiah Manajemen dan Bisnis, Vol. 18, No. 2, Oktober 2017.

Budi, Doddy Astya, "Pengaruh Pendidikan Kewirausahaan dan Motivasi Kewirausahaan Terhadap Keterampilan Berwirausaha Mahasiswa Universitas 17 Agustus 1945 Jakarta", Journal For Business And Entrepreneur, Vol.1, No.1, Juli - Desember 2017.

Christianingrum dan Erita Rosalina, "Pengaruh Pembelajaran Kewirausahaan Terhadap Minat Berwirausaha", Integrated Journal of Business and Economics, Vol.1, No. 1, 2017.

Direktorat Jenderal Pembelajaran dan Kemahasiswaan. Fungsi Direktorat Kemahasiswaan , belmawa.ristekdikti.go.id, 9 Desember 2016.

Farid. Kewirausahaan Syariah. Jakarta: Kencana, 2017.

Humas Kementerian Koperasi dan UKM, "Ratio Wirausaha Indonesia Naik Jadi 3,1” (Siaran Pers), www.depkop.go.id, 11 Maret 2017.

Katadata.co.id, diakses tanggal 29 Oktober 2018.

Kuwado, Fabian Januarius, "Jumlah Entrepreneur Di Indonesia Jauh Di Bawah Negara Maju, Ini Kata Jokowi” (News Nasional). www.Kompas.com, 5 April 2018.

"Menteri Puspayoga Sebut Rasio Wirausaha sudah Capai 7 Persen Lebih" (Berita Media), www.depkop.go.id, 6 Juni 2018.

Tiga Tahapan Pembangunan Menuju Indonesia 2045" (Beranda Aktual), presidenri.go.id,27 Maret 2017, diakses tanggal 6 November 2018.

Santoso, Agus. 9 Kunci Sukses Entrepreneur. Cet. I; Jakarta: Bestari, 2016.

Suherman, Eman, "Desain Pembelajaran Kewirausahaan”, dalam Christianingrum dan Erita Rosalina, Pengaruh Pembelajaran Kewirausahaan Terhadap 
Minat Berwirausaha (Integrated Jornal of Business and Economics, Vol.1, No. 1, 2017), h. 49.

Suryana. Kewirausahaan: Kiat dan Proses Menuju Sukses. Edisi 4; Jakarta: Salemba Empat, 2017.

Susilaningsih, "Pendidikan Kewirausahaan Di Perguruan Tinggi: Pentingkah Untuk Semua Profesi?”, Jurnal Economia. Vol. 11, No. 1, April 2015.

Usman, Marzuki. "Kewirausahaan dalam Birokrasi Salah Satu Langkah Antisipatif Menghadapi Globalisasi”, dalam Suryana, eds., Kewirausahaan: Kiat dan Proses Menuju Sukses. Edisi 4; Jakarta: Salemba Empat, 2017.

Wibowo, Agus, "Pendidikan Kewirausahaan (Konsep dan Strategi)", dalam Doddy Astya Budy, eds., Pengaruh Pendidikan Kewirausahaan dan Motivasi Kewirausahaan Terhadap Keterampilan Berwirausaha Mahasiswa Universitas 17 Agustus 1945 Jakarta (Journal For Business And Entrepreneur, Vol.1, No.1, Juli - Desember 2017).

Widnyana, I Wayan, dkk, "Pengaruh Pemberian Mata Kuliah Kewirausahaan Terhadap Minat WirausahaEkonomi Kreatif Pada Mahasiswa Unmas Denpasar", Jurnal Bakti Masyarakat Indonesia, Vol. 1, No. 1, Mei 2018.

Wiratno, Siswo, "Pelaksanaan Pendidikan Kewirausahaan Di Pendidikan Tinggi". Jurnal Pendidikan dan Kebudayaan. Vol. 18, No. 4, Desember 2012.

Zubaedi, "Urgensi Pendidikan Kewirausahaan Di Kalangan Mahasiswa PTKI", Madania, Vol. 19, No. 2, Desember 2015. 